\title{
Decision Making Styles and Stress Coping Strategies among Alochol Addicts
}

\author{
Parameswari. $\mathrm{J}^{1 *}$
}

\section{ABSTRACT}

In a demanding situation, a normal healthy adult makes decision based on experience, expertise or seeking knowledge from others or rely on own intuition. But a person under the influence of alcohol tends to be impulsive which hinders his effective decision making process. Situations demanding deeper levels of thought can cause stress. A person under the influence of drug may not be able to assess the problem clearly and therefore may not use an appropriate strategy. With this hypothetical belief, the present study was done to know if styles of making decision have a significant influence on stress coping strategies of alcohol addicts. Further the researcher also want to know if there was significant difference in stress coping strategies used among addicts based on their age and place of residence. The sample for the study was the alcohol addicts seeking treatment in de-addiction centers in Salem and Erode (Tamil Nadu). 150 alcohol addicts were randomly chosen form 8 centers. Regression and t-test were used to analyse the collected data. The results revealed that vigilance style of making decision has a significant influence on acceptance, refocus on planning and catastrophizing strategies of coping with stress. There was a significant difference in self-blame, other blame and positive refocusing based on the age of the addicts. Further there was a significant difference in rumination and refocus on planning among alcohol addicts based on their place of residence.

Keywords: Decision-Making Styles, Stress Coping, Addicts, Age, Influence.

Decision making is a cognitive process of selecting an alternative among the possible alternatives. A person's decision making style depends on how he thinks and assesses information (Myers, 1975). This indicates that a person's decision making style depends on his cognitive style. All of us make a decision each day. Some decisions may be easy and some may be difficult. A situation where one has to make decision like "what to cook, what dress to wear for the day" is not considered as real decision making situation because no deeper level thought process is required in these situations. Here the styles of making decision has little role. In a demanding situation, a normal healthy adult makes decision based on experience, expertise or seeking knowledge from others or rely on own intuition. But a person under the influence of alcohol tends to be impulsive. This impulsive nature influences their decision. Research has

\footnotetext{
${ }^{1}$ Assistant Professor, Department of Psychology, Periyar University, Salem, TN, India *Corresponding Author

(C) 2015 I Parameswari J; licensee IJIP. This is an Open Access Research distributed under the terms of the Creative Commons Attribution License (http://creativecommons.org/licenses/by/2.0), which permits unrestricted use, distribution, and reproduction in any Medium, provided the original work is properly cited.
} 
proved that high binge drinkers showed impairment on impulse control task (Townshend, Kambouropoulos, Griffin, Hunt \&Milani, 2014) and impairment in making decision is related to impulsiveness (Tomassini, Struglia, Spaziani, Pacifico, Stratta\& Rossi, 2012).

Situations demanding deeper levels of thought can cause stress, especially if one finds it difficult to choose among the alternatives. Ability to cope with stress varies from person to person depending on their personality, social support, etc. A healthy person can think and assess the problem and choose a better coping strategy. Whereas a person under the influence of drug may not be able to assess the problem or situation clearly and therefore may not use an appropriate strategy. Brady and Back (2012) in their study found that excessive alcohol users use maladaptive stress coping strategies. Osmany et al (2014) reported that alcohol dependents perceived low social support, used emotion focused coping style (Miller et al., 2014) and avoidant-oriented coping strategies (Gerry et al., 2012).

\section{OBJECTIVES}

1. To know if stress coping strategies is influenced bystyles of making decision among alcohol addicts.

2. To study stress coping strategy of alcohol addicts.

\section{HYPOTHESIS}

1. Stylesmaking decision will have a significant influence on stress coping strategies of alcohol addicts.

2. There will be a significant difference in stress coping strategies among alcohol addicts based on their age.

3. There will be a significant difference in stress coping strategies among alcohol addicts based on their place of residence.

\section{TOOLS USED}

Flinder's decision making questionnaire - II (Mann, 1998) was used to measure the decision making styles. This questionnaire measures six styles namely vigilance, hyper vigilance, defensive avoidance, procrastination, buck-passing and rationalization. This tool has both content and faces validity. The intrinsic validity of the tool ranged between 0.52 and 0.91 for the six styles. The reliability for the six styles was $0.82,0.57,0.60,0.47$ and 0.50 respectively.

Cognitive emotion regulation questionnaire (Garnefski, Kraaji \& Spinhoven, 2001) was used to measure the stress coping strategies. The nine strategies measured are self-blame, acceptance, rumination, positive refocusing, refocus on planning, positive reappraisal, putting into perspective, catastrophizing and other-blame. The tool possessed high content validity and the reliability ranged between 0.75 to 0.0 .86 for the subscales.

\section{SAMPLE}

Alcohol addicts form the sample of this study. 150 alcohol addicts were randomly chosen from de-addiction centers in Salem and Erode. 


\section{RESULTS AND DISCUSSION}

Table1: Influence of decision making styles on stress coping strategies among alcohol addicts.

\begin{tabular}{|c|c|c|c|c|c|c|}
\hline \multirow[t]{2}{*}{$\begin{array}{l}\text { Independent } \\
\text { variable }\end{array}$} & \multirow[t]{2}{*}{$\begin{array}{l}\text { Dependent } \\
\text { variable }\end{array}$} & \multicolumn{2}{|c|}{$\begin{array}{l}\text { Unstandardized } \\
\text { coefficient }\end{array}$} & \multirow[t]{2}{*}{$\beta$} & \multirow[t]{2}{*}{$\mathrm{t}$} & \multirow[t]{2}{*}{$\begin{array}{l}\text { Model } \\
\text { Summary }\end{array}$} \\
\hline & & B & $\begin{array}{l}\text { Std } \\
\text { Error }\end{array}$ & & & \\
\hline \multirow[t]{3}{*}{ Vigilance } & Acceptance & 0.33 & 0.10 & 0.29 & 3.28 & $\begin{array}{l}R^{2}=0.09 \\
F=2.51 \\
P<0.05\end{array}$ \\
\hline & $\begin{array}{ll}\text { Refocus } & \text { on } \\
\text { planning } & \end{array}$ & 0.51 & 0.11 & 0.38 & 4.54 & $\begin{array}{l}R^{2}=0.18 \\
F=5.36 \\
P<0.01\end{array}$ \\
\hline & Catastrophizing & -0.28 & 0.10 & -0.24 & -2.69 & $\begin{array}{l}R^{2}=0.10 \\
F=2.73 \\
P<0.05\end{array}$ \\
\hline
\end{tabular}

The above table shows the significant influence of vigilance style of making decision on acceptance, refocus on planning and catastrophizing. Hence, hypotheses 1 stating "Styles of making decision will have a significant influence on stress coping strategies” is partially accepted. A vigilant decision maker assesses the information and then makes a decision. The under treatment alcohol addicts who use vigilance style of making decision tend to accept the stressful situation because they may believe that they are responsible for whatever has happened. Therefore they think of what best can be done to minimize the stress. People who are vigilant gather information related to their problem. In this process there are chances that they become aware of the problem of others and compare it with that of their own. If they perceive their state as less worse, they will feel better. Also, they will learn the ways of handling stress (castastrophizing). This may motivate them to think of the other ways of handling the problematic situation or may even change their perception of the problem (positive reappraisal). This indicates that they have started accepting the situation and they may learn to adjust and live with it (acceptance). 
Decision Making Styles and Stress Coping Strategies among Alochol Addicts

Table 2: Difference in stress coping strategies based on age

\begin{tabular}{|c|c|c|c|c|}
\hline Stress coping strategies & Age in years & M & SD & $\mathrm{t}$ \\
\hline \multirow[t]{2}{*}{ Self-blame } & Below 40 & 10.95 & 3.19 & \multirow[t]{2}{*}{$1.98^{*}$} \\
\hline & Above 40 & 10.10 & 1.98 & \\
\hline \multirow[t]{2}{*}{ Acceptance } & Below 40 & 11.28 & 2.67 & \multirow[t]{2}{*}{$1.20^{\mathrm{NS}}$} \\
\hline & Above 40 & 10.77 & 2.45 & \\
\hline \multirow[t]{2}{*}{ Rumination } & Below 40 & 11.39 & 2.74 & \multirow[t]{2}{*}{$0.60^{\mathrm{NS}}$} \\
\hline & Above 40 & 11.14 & 2.31 & \\
\hline \multirow[t]{2}{*}{ Positive refocusing } & Below 40 & 11.95 & 2.92 & \multirow[t]{2}{*}{$0.53^{\mathrm{NS}}$} \\
\hline & Above 40 & 11.73 & 2.04 & \\
\hline \multirow[t]{2}{*}{ Refocus on planning } & Below 40 & 12.51 & 3.48 & \multirow[t]{2}{*}{$0.20^{\mathrm{NS}}$} \\
\hline & Above 40 & 12.41 & 2.41 & \\
\hline \multirow[t]{2}{*}{ Positive reappraisal } & Below 40 & 11.49 & 2.55 & \multirow[t]{2}{*}{$2.23^{*}$} \\
\hline & Above 40 & 12.32 & 1.99 & \\
\hline \multirow[t]{2}{*}{ Putting into perspective } & Below 40 & 11.30 & 2.66 & \multirow[t]{2}{*}{$0.33^{\mathrm{NS}}$} \\
\hline & Above 40 & 11.45 & 2.73 & \\
\hline \multirow[t]{2}{*}{ Catastrophizing } & Below 40 & 10.97 & 2.64 & \multirow[t]{2}{*}{$0.56^{\mathrm{NS}}$} \\
\hline & Above 40 & 11.23 & 2.76 & \\
\hline \multirow[t]{2}{*}{ Other-blame } & Below 40 & 10.72 & 2.73 & \multirow[t]{2}{*}{$2.17^{*}$} \\
\hline & Above 40 & 09.83 & 2.28 & \\
\hline
\end{tabular}

*Significant at 0.05 level NS- Not Significant

From the above table it is found that based on age there is a significant difference in three strategies namely self-blame, positive reappraisal and other blame. Therefore hypothesis 2 is partially accepted. It is observed that alcohol addicts below 40 years of age have scored high in self-blame and other blame; and low in positive refocusing. This shows that compared to alcohol addicts aged above 40 years, addicts below 40 years of age blame themselves and others for their state. They fail to learn from the situation. This indicates that they may experience high level of stress. Alcohol addicts aged above 40 years may look for the positive sides of an issue. Also they may think that they can learn and become strong form their experience.

Table 3: Difference in stress coping strategies among alcohol addicts based on their place of residence.

\begin{tabular}{|c|c|c|c|c|}
\hline Stress coping strategies & Place of residence & $\mathrm{M}$ & SD & $\mathrm{t}$ \\
\hline \multirow{2}{*}{ Self-blame } & Urban & 10.94 & 2.74 & \multirow[t]{2}{*}{$1.90^{\mathrm{NS}}$} \\
\hline & Rural & 10.10 & 2.62 & \\
\hline \multirow[t]{2}{*}{ Acceptance } & Urban & 11.33 & 2.68 & \multirow[t]{2}{*}{$1.46^{\mathrm{NS}}$} \\
\hline & Rural & 10.71 & 2.43 & \\
\hline \multirow[t]{2}{*}{ Rumination } & Urban & 11.81 & 2.54 & \multirow[t]{2}{*}{$2.84 *$} \\
\hline & Rural & 10.66 & 2.43 & \\
\hline \multirow[t]{2}{*}{ Positive refocusing } & Urban & 12.16 & 2.49 & \multirow[t]{2}{*}{$1.63^{\mathrm{NS}}$} \\
\hline & Rural & 11.49 & 2.56 & \\
\hline \multirow[t]{2}{*}{ Refocus on planning } & Urban & 12.99 & 3.00 & \multirow[t]{2}{*}{$2.32 *$} \\
\hline & Rural & 11.86 & 2.94 & \\
\hline \multirow[t]{2}{*}{ Positive reappraisal } & Urban & 11.98 & 2.34 & \multirow[t]{2}{*}{$0.49^{\mathrm{NS}}$} \\
\hline & Rural & 11.79 & 2.33 & \\
\hline \multirow[t]{2}{*}{ Putting into perspective } & Urban & 11.71 & 2.82 & \multirow[t]{2}{*}{$1.67^{\mathrm{NS}}$} \\
\hline & Rural & 10.99 & 2.48 & \\
\hline \multirow[t]{2}{*}{ Catastrophizing } & Urban & 11.29 & 2.75 & \multirow{2}{*}{$0.94^{\mathrm{NS}}$} \\
\hline & Rural & 10.87 & 2.62 & \\
\hline \multirow[t]{2}{*}{ Other-blame } & Urban & 10.34 & 2.61 & \multirow[t]{2}{*}{$0.19^{\mathrm{NS}}$} \\
\hline & Rural & 10.26 & 2.52 & \\
\hline
\end{tabular}

*Significant at 0.05 level NS- Not Significant 
The above table makes it clear that there is a significant difference in two dimensions namely rumination and refocus on planning with regard to place of residence. Therefore, hypothesis 3 is partially accepted. Alcohol addicts from urban area have high scores in rumination and refocus on planning compared to addicts from rural areas. In general, the social support is high in villages mainly because villagers belong to same community and they have been together for long years. Their relationship is more open and genuine; therefore, they may discuss their problems with others. This helps them to handle the problem in a better way. Whereas, in cities different community people live together and the relationship is not all that strong, open and genuine all the time. Therefore, people may hesitate to discuss their issues with others. They may keep the problem within themselves and think about it all the time.

\section{CONCLUSIONS}

1. Vigilance style of making decision has a significant influence on acceptance, refocus on planning and catastrophizing strategies of coping with stress.

2. There is a significant difference in self-blame, other blame and positive refocusing based on the age of the addicts.

3. There is a significant difference in rumination and refocus on planning among alcohol addicts based on their place of residence.

4.

\section{REFERENCES}

Brady, K. T., \& Back, S. E. (2012).Childhood trauma, posttraumatic stress disorder and alcohol dependence.Alcohol Research: Current Reviews, 34(4), 408-413.

Garnefski, N., Kraaij, V., \&Spinhoven, P. H. (2001). Negative life events, cognitive emotion regulation and emotional problems.Personality and Individual Differences, 30, 13111327.

Mann, L., Radford, M., Burnett, P., Ford, S., Bond, M., Leung, K., Nakamura, H., Vaughan, G., \& Yang, K-S.(1998).Cross cultural differences in self-reported decision making style and confidence.International Journal of Psychology,33(5), 325-335.

Millere, A., Millere, E., Zumente, Z., Caune, L., Sudraba, V., Deklava, L., Vagale, A., \&Millere, I. (2014). Analysis of dynamics of treatment motivation and stress coping of substance use disorders patients in minnesota program of Latvia. International Journal of Collaborative Research on Internal Medicine \& Public Health, 6(7), 216-225.

Myers (1975) in Boundless (2015).Decision-making styles.Boundless Management.Retrieved from https:/www.boundless.com/management/textbooks/boundless-managementtextbook/decision-making-10/decision-making-in-management-75/decision-makingstyles-367-1521/

Tomassini, A., Struglia, F., Spaziani, D., Pacifico, R., Stratta, P., \& Rossi, A. (2012). Decision making, impulsivity and personality traits in alcohol-dependent subjects.The American Journal on Addiction/ American Academy of Psychiatrist in Alcoholism and Addiction, 21(3), 263-267.

Townshend, J. M., Kambouropoulos, N., Griffin, A., Hunt, F. J., \&Milani, R. M. (2014). Binge drinking, reflection impulsivity, and unplanned sexual behavior: impaired decisionmaking in young social drinkers. Alcoholism, Clinical and Experimental Research, 38(4), 1143-1150. 